\title{
The effect of biotin and zinc supplementation on dairy cow hoof health and milk quality
}

\author{
Amandeep Singh ${ }^{1}$, Swaran S. Randhawa ${ }^{1}$, and Raj S. Singh ${ }^{2 *}$ \\ ${ }^{I}$ Department of Veterinary Medicine, College of Veterinary Science, Guru Angad Dev Veterinary and Animal \\ Sciences University, Ludhiana, Punjab, India \\ ${ }^{2}$ Department of Teaching Veterinary Clinical Complex, College of Veterinary Science, Guru Angad Dev \\ Veterinary and Animal Sciences University, Ludhiana, Punjab, India
}

\section{SINGH, A., S. S. RANDHAWA, R. S. SINGH: The effect of biotin and zinc supplementation on dairy cow hoof health and milk quality. Vet. arhiv 89, 799-820, 2019.}

\begin{abstract}
The objective of this field study was to evaluate the effect of biotin and zinc sulphate $\left(\mathrm{ZnSO}_{4}\right)$ supplementation on hoof health and milk quality in lactating dairy cows. Clinically lame $(\mathrm{n}=31)$ and healthy $(n=28)$ cows were selected on the basis of locomotion scores (LS), and were randomly assigned to either the 'treatment group' [clinically lame treatment $(\mathrm{CLT})=17$ and healthy treatment $(\mathrm{HT})=15$; supplemented with $1 \mathrm{~g}$ of $2 \%$ biotin and $4 \mathrm{~g}$ of $\mathrm{ZnSO}_{4}$ daily for $4 \mathrm{mo}$ ] or the 'control group' [clinically lame control (CLC) $=14$ and healthy control $(\mathrm{HC})=13]$. Locomotion scores, body condition scores, and milk quality and yield were estimated before and after the end of the study. Also, hoof trimming was undertaken before and after the supplementation period, and claw lesions were observed for type and severity. Sole thickness (ST) was measured by ultrasonography in some of the back claws in treatment and control cows. Data were analyzed using likelihood ratio Chi-square and paired $t$ tests. At the end of the study, there was a significant improvement in the LS $(\mathrm{P}<0.001)$; heel horn erosion score $(\mathrm{P}<0.05)$; overgrown sole score $(\mathrm{P}<0.001)$; and sole haemorrhage score $(\mathrm{P}<0.01)$ in the CLT cows. Some of these lesion scores deteriorated in the HC cows. Sole thickness increased in the CLT cows $(\mathrm{P}<0.05)$, whereas it decreased in the CLC cows $(\mathrm{P}<0.05)$. The milk somatic cell count (SCC) decreased $(\mathrm{P}<0.05)$, whereas milk yield $(\mathrm{P}<0.001)$ and fat content $(\mathrm{P}<0.05)$ increased in the CLT cows. A significant decline in the average SCC $(\mathrm{P}<0.05)$ in the HT was also observed. We concluded that concurrent supplementation with biotin and $\mathrm{ZnSO}_{4}$ seems to be beneficial for correction and prevention of claw lesions, as well as improvement of milk quantity and quality in clinically lame dairy cows.
\end{abstract}

Key words: dairy cow; lameness; claw lesions; biotin; zinc; milk quality

\footnotetext{
*Corresponding author:

Assoc. Prof. Raj Sukhbir Singh, PhD, Department of Teaching Veterinary Clinical Complex, College of Veterinary Science, Guru Angad Dev Veterinary and Animal Sciences University, Ludhiana - 141 004, Punjab, India, Phone: +91 1612414007 ; Fax:+91 1612400 822, E-mail: rsbs_66@rediffmail.com
} 
A. Singh et al.: Biotin-zinc supplementation in relation to hoof health and milk quality

\section{Introduction}

Bovine lameness is one of the serious problems faced by the dairy industry (BARKER et al., 2010) due to its negative impact on the fertility (MORRIS et al., 2011), milk quality (GREEN et al., 2014), and longevity (BOOTH et al., 2004; CRAMER et al., 2009) of dairy cows. Irrespective of whether the foot lesions cause lameness, they have a serious effect on animal welfare (BRUIJNIS et al., 2012), as the affected cows spend much more time in the cubicles than feeding (SINGH et al., 1993) and this could result in incomplete nutrition, leading to loss of body condition (GOMEZ and COOK, 2010).

The modern dairy industry is based on the implementation of more rigorous technologies for production, such as housing in stalls, stress from high milk yield and intensive concentrate feeding, which are among the important predisposing risk factors associated with the lameness (SOLANO et al., 2016). Also, abrupt changes in nutrition, such as sudden increases in rapidly fermented carbohydrates and/or a decrease in the amount of fiber content in the diet, are considered to be the main causes of lameness in dairy cows (LIVESEY and FLEMING, 1984). These predisposing conditions consequently lead to both structural and biochemical alterations within the hoof structure (TARLTON et al., 2002; KNOTT et al., 2007). Reduced claw horn quality contributes to the development of secondary foot lesions, such as sole ulcers, white line disease, underrun sole, overgrown sole, and heel horn erosion (TARLTON et al., 2002). Approximately $90 \%$ of the causes of lameness involve foot lesions (MURRAY et al., 1996; SHEARER and VAN AMSTEL, 2013).Today, lameness and claw lesions have emerged as a recurrent health problem among dairy cows (WARNICK et al., 2001; CAPION et al., 2008), and are common reasons for culling of these cows (BOOTH et al., 2004; CRAMER et al., 2009).

In these circumstances, the search for preventive and therapeutic strategies to reduce the deleterious impact of lameness is of great importance (WINCKLER and WILLEN, 2001). Various approaches, such as claw trimming (TOUSSAINT-RAVEN et al., 1985; MANSKE et al., 2002), foot blocks (MIGUEL-PACHECO et al., 2016), and foot baths (BERGSTEN et al., 2006) have been suggested for prophylaxis and therapeutic care of the hoof. Also, studies have suggested that correct nutrition of dairy cows is critical for synthesis of a resilient claw horn capsule, capable of withstanding environmental challenges (TOMLINSON et al., 2004). The role of nutraceuticals, such as amino acids (such as cysteine and methionine), minerals (such as zinc, copper, selenium, biotin, manganese and cobalt) and vitamins (such as biotin and vitamin E) have been evaluated for their associations with cow hoof health and production (HEDGES et al., 2001; BALLANTINE et al., 2002, BERGSTEN et al., 2003; KELLOGG et al., 2004; DRENDEL et al., 2005; NOCEK et al., 2006, RANDHAWA et al., 2012, GHOLAM et al., 2013). Among these, zinc ( $\mathrm{Zn}$ ) and biotin have shown promising results in terms of amelioration of claw lesions in dairy cattle (MOORE et al., 1989; LISCHER et al., 2002). 


\section{A. Singh et al.: Biotin-zinc supplementation in relation to hoof health and milk quality}

Biotin, a water soluble vitamin also known as vitamin $\mathrm{H}$, is naturally present in plants and also synthesized in the rumen by microbes. It is identified as an essential component for the epidermal cell differentiation (FRITSCHE et al., 1991) and keratinization (MULLING et al., 1999) of the hoof structure. In addition to improving horn quality by promoting horn formation (HIGUCHI and NAGAHATA, 2001), biotin also improves conception rates (BERGSTEN et al., 2003), and milk quality and quantity (ZIMMERLY and WEISS, 2001) in dairy cattle.

Zinc has also been shown to be crucial for maintenance of claw integrity (NOCEK et al., 2000). Lame cows have a lower concentration of $\mathrm{Zn}$ in their hoof horns than sound cows (BAGGOTT et al., 1988). Addition of supplemental $\mathrm{Zn}$ to growing and finishing cattle diets has improved hoof quality parameters (KESSLER et al., 2003). Furthermore, the supplementation of $\mathrm{Zn}$ has been reported to reduce milk somatic cell counts (SCC) (KINAL et al., 2005).

With the introduction of organized dairy farming in Punjab, lameness is increasing at an alarming rate. It needs to be controlled at an early stage so that subclinical cases of lameness can be prevented from becoming clinical. Previous supplementation trials have used either biotin or $\mathrm{Zn}$ to elucidate their effects on correction of claw lesions and improvement of milk quality (POTZSCH et al., 2003, RANDHAWA et al., 2012). The aim of this study was to evaluate the composite effect of supplemental biotin and $\mathrm{Zn}$ on the locomotion score, body condition score, claw lesion score, and milk yield and quality in Holstein Friesian-Sahiwal crossbred dairy cows.

\section{Materials and methods}

Farm management. The present study was carried out on Holstein Friesian-Sahiwal crossbred dairy cows, kept at the three commercial dairy farms from February to July 2016. The farms were selected intentionally as they had similar types of housing and general management practices. For most of the year, cows were provided with chopped seasonal green fodder, mixed with wheat straw, and silage was fed during the scarcity period. Concentrate feed was provided according to the milk production levels. The cows were not supplemented with a mineral mixture at any of the farms. Fresh water was available $a d$ lib all the time. Animals were housed in sheds with both concrete and sandbedded floors. The floor was cleaned manually 2 to 3 times daily. All the cows were milked twice daily within the shed itself, with the help of bucket type milking machines. Hoof trimming was not practiced on a regular basis, but it was only performed selectively in animals with overgrown hoofs.

Locomotion score and selection of cows. During the month of February 2016, i.e., before the start of the treatment trial, locomotion scores (LS) were evaluated simultaneously by 2 experienced veterinarians on a 5 -point scale, and the final scores 


\section{A. Singh et al.: Biotin-zinc supplementation in relation to hoof health and milk quality}

were assigned according to the consensus of these observers. In brief, each cow was allowed to walk through a passage on a flat surface and any deviation from the normal gait was recorded subjectively, where score 0 corresponded with no-gait abnormality (sound); score 1 = mild lameness with a slight disparity from the normal gait symmetry; score 2 = moderate lameness with reasonable and constant gait asymmetry; score $3=$ severe lameness with clear gait asymmetry; and score $4=$ a non-ambulatory or recumbent cow. None of the cows at the dairy farms in this study had a LS of 4.

All cows with an LS of 2 and 3 were grouped as clinical lame cows $(n=31)$, and cows with a locomotion score of 0 were grouped as non-lame healthy cows $(n=28)$. The enrolled cows were in different stages of lactation (mean 152.6 \pm 9.8 days; range 30 to 300 days) and parities (mean $2.6 \pm 0.1$; range 1 to 5). Clinically lame and non-lame cows were further randomly assigned to the two groups: 1) Treatment group = clinically lame treatment (CLT; $\mathrm{n}=17)$ and healthy treatment (HT; $\mathrm{n}=15)$; and 2) Control group $=$ clinically lame control (CLC; $n=14)$ and healthy control $(\mathrm{HC} ; \mathrm{n}=13)$. The cows were stratified according to the stage of lactation (CLT: $137.4 \pm 14.3$ days, range 60 to 240 days; HT: $143.9 \pm 21$ days, range 45 to 280 days; CLC: $161.1 \pm 22.5$ days, range 30 to 300 days; and HC: $173.5 \pm 21.7$ days, range 45 to 300 days) and parity (CLT: $2.8 \pm 0.2$, range 1 to 5 ; HT: $2.5 \pm 0.3$, range 1 to 5; CLC: $2.6 \pm 0.3$, range 1 to 5; and HC: $2.5 \pm 0.2$, range 1 to 4$)$.

Treatment trial. The cows in the treatment groups (CLT and HT) were fed with the concentrate ration, supplemented with $1 \mathrm{~g}$ of $2 \%$ biotin/cow/day along with $4 \mathrm{~g}$ of zinc sulphate $\left(\mathrm{ZnSO}_{4}\right)$ /cow/day at the time of morning milking for 4 months starting from March to June 2016. Cows in the control groups (CLC and HC) were only fed concentrate ration. Other management conditions remained the same throughout the study period.

Parameters recorded. During the month of February 2016, i.e., before the start of the treatment trial, and secondly, during the month of July 2016, i.e., after the end of the treatment trial, the following parameters were recorded:

Body condition score. Body condition score (BCS) evaluation was performed by the same 2 experienced veterinarians using the 5-point scale of FERGUSON et al. (1994), where a score of 1 was assigned to an emaciated cow and a score of 5 was assigned to an obese cow.

Claw lesions. All the four feet of each cow were lifted and lesions were recorded as mentioned in Table 1 (Supplementary figures). Hoofs were also trimmed by removing a layer of approximately $1 \mathrm{~mm}$ of the hoof horn from the weight bearing surface, except in cows with overgrown soles where the claw soles were balanced accordingly. Claw lesions were scored for severity, on a scale of 1 to 3 ( 1 for a mild lesion and 3 for a severe lesion) as described by RANDHAWA et al. (2008) (Table 1). 
A. Singh et al.: Biotin-zinc supplementation in relation to hoof health and milk quality

Table 1. Criteria for severity scoring of claw lesions in lactating dairy cows

\begin{tabular}{|l|l|l|l|}
\hline Claw lesion & \multicolumn{1}{|c|}{ Score 1 (Mild) } & \multicolumn{1}{|c|}{ Score 2 (Moderate) } & \multicolumn{1}{c|}{ Score 3 (Severe) } \\
\hline $\begin{array}{l}\text { Heel horn } \\
\text { erosion }\end{array}$ & Pitting of the heel & $\begin{array}{l}\text { Formation of small } \\
\text { craters }\end{array}$ & $\begin{array}{l}\text { Completely eroded heel or } \\
\text { big v-shaped craters }\end{array}$ \\
\hline $\begin{array}{l}\text { Sole } \\
\text { hemorrhage }\end{array}$ & $\begin{array}{l}\text { General reddening of } \\
\text { sole or small petechial or } \\
\text { ecchymotic hemorrhages }\end{array}$ & $\begin{array}{l}\text { Visible hemorrhages } \\
\text { distributed in half of the } \\
\text { sole or bright red spots } \\
\text { in a particular area }\end{array}$ & $\begin{array}{l}\text { Visible hemorrhages } \\
\text { distributed in more than } \\
\text { half of the sole or dark red } \\
\text { spot in a particular area }\end{array}$ \\
\hline $\begin{array}{l}\text { Underrun } \\
\text { sole }\end{array}$ & $\begin{array}{l}\text { Underrunning covering } \\
1 / 3^{\text {rd }} \text { of sole }\end{array}$ & $\begin{array}{l}\text { Underrunning covering } \\
\text { 2/3 } 3^{\text {rd }} \text { of sole }\end{array}$ & $\begin{array}{l}\text { Underrunning of the whole } \\
\text { of the sole }\end{array}$ \\
\hline $\begin{array}{l}\text { Overgrown } \\
\text { sole }\end{array}$ & $\begin{array}{l}\text { Overgrowth of sole } \\
\text { restricted only to sole } \\
\text { bulb area (covering } 1 / 3^{\text {rd }} \\
\text { of the solar surface) }\end{array}$ & $\begin{array}{l}\text { Overgrowth of sole } \\
\text { covering } 2 / 3^{\text {rd }} \text { of the } \\
\text { solar surface }\end{array}$ & $\begin{array}{l}\text { Overgrowth of sole } \\
\text { covering the whole of the } \\
\text { solar surface }\end{array}$ \\
\hline
\end{tabular}

Sole thickness. Sole thickness (ST) was measured with the help of a portable ultrasound machine (SonoSiteM-Turbo ${ }^{\circledR}$, FUJIFILM SonoSite, Inc. WA, USA) using a 2-5 $\mathrm{MHz}$ convex probe, as per the technique described previously (VAN AMSTEL et al., 2004). Each cow was restrained properly in a lameness chute and the claws of the back feet were trimmed before performing ultrasonography. Since thickness is variable in different anatomical locations within the sole, the measurements were taken at a specific area, which was marked on the sole bulb area at a point where the longitudinal midline intersects the horizontal line drawn at the widest portion of the sole (Fig. 1). The internal margin of the sole epidermis was visualized as a thin hyperechoic line of a continuous nature above an anechoic region (Fig. 2). The ST was measured as the distance (mm) from the external sole surface to the internal margin of the sole. Measurements were made on 36 back claws of the CLT cows; 28 back claws of the HT cows; 20 back claws of the CLC cows; and 12 back claws of the HC cows.

Milk yield and milk composition. The average daily milk yield $(\mathrm{kg})$ during the 3 consecutive days prior to the study and 3 consecutive days after the end of the study was calculated. Also, about $20 \mathrm{~mL}$ of the cow composite milk (CCM) sample from each cow was collected in a plastic container on two occasions (before and after the treatment period) and subjected for estimation of milk compositional parameters. Samples were kept in an ice box and transported to the laboratory where,after thawing, the milk SCC was estimated using an automatic somatic cell counter (SomaScope Smart, DELTA Instruments, The Netherland). Both absolute $\left(\times 10^{3}\right.$ cells $\left./ \mathrm{mL}\right)$ and $\log _{10} \mathrm{SCC}$ cells/ $\mathrm{mL}$ values were calculated. The biochemical composition of milk i.e. fat, protein and lactose, was analyzed using an automatic milk analyzer (Lactoscan LA, Milkotronic Ltd, Bulgaria) and the results were expressed in $\%(\mathrm{w} / \mathrm{v})$. 
A. Singh et al.: Biotin-zinc supplementation in relation to hoof health and milk quality

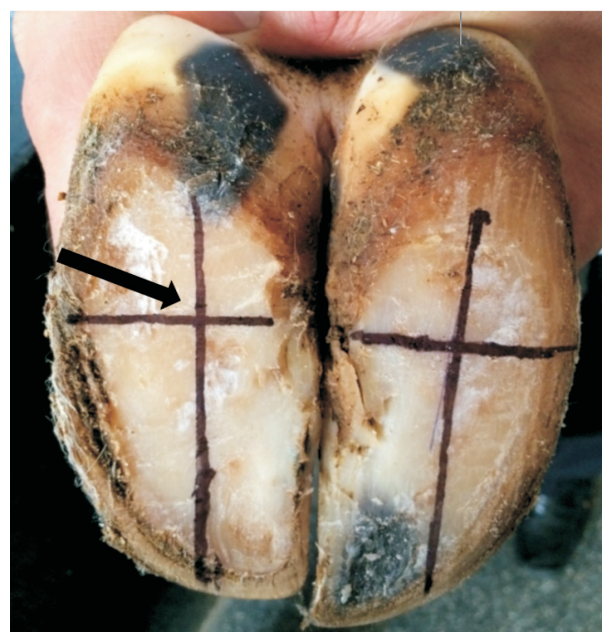

Fig. 1. Point (arrow) where the probe was placed while measuring sole thickness

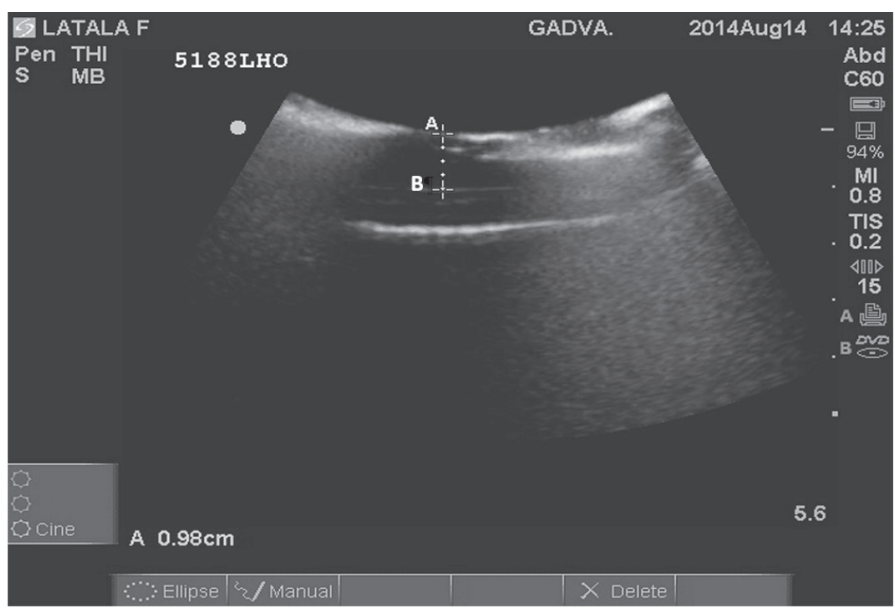

Fig. 2. Ultrasonography measurement of sole thickness $(A=$ external sole surface, $B=$ internal sole epidermal margin) 
A. Singh et al.: Biotin-zinc supplementation in relation to hoof health and milk quality

Statistical analysis. For the purpose of statistical analysis, grouping of categorical variables was done as followed:

Locomotion score: $\mathrm{LS}$ of $0=$ Sound; $\mathrm{LS}$ of 1 to $2=$ Mild to moderate; and LS of $3=$ Severe.

Body condition score: $\mathrm{BCS}$ of $<3=$ Low; $\mathrm{BCS}$ of 3 to $3.5=\mathrm{Good}$; and $\mathrm{BCS}$ of $>4$ = High

Claw lesion score: Claw without lesions $=$ Sound; lesion score of 1 to $2=$ Mild to moderate; and lesion score of $3=$ Severe.

All statistical analyses were performed with Minitab statistical software (Minitab Inc., Version 14.2, State College, PA, USA). Frequencies and proportions were calculated for categorical variables, and means \pm standard errors (SE) were calculated for continuous variables. The effects of supplementation of biotin and $\mathrm{ZnSO}_{4}$ on LS, BCS and claw lesion scores in clinically lame and non-lame healthy cows were assessed using the likelihood ratio Chi-square test. The paired $t$-test was used to evaluate the effect of supplementation on ST, and milk related parameters in clinically lame and non-lame healthy cows. A P value $\leq 0.05$ was considered significant.

\section{Results}

Descriptive statics. At the start of the study, of 31 clinically lame cows, $41.9 \%$ had LS classified as severe, and 54.8 and $12.9 \%$ had BCS classified as low and high, respectively. With respect to non-lame healthy cows $(\mathrm{n}=28), 21.4$ and $17.9 \%$ had BCS categorized as low and high, respectively.

About 50\% (126/248) of the claws from clinically lame cows were without any type of lesions, i.e. they were sound, and about $10 \%(24 / 248)$ had at least two different types of lesions. In $68.1 \%$ of the claws, heel horn erosions were absent (classified as sound), in $24.2 \%$ of the claws, lesion scores were mild to moderate, and in $7.7 \%$ of the claws lesion scores were severe. Similarly, the percentage of claws classified as free from overgrown sole lesions was $89.1 \%$ (sound) leaving $10.9 \%$ with mild to moderate overgrown sole lesion scores. The proportion of claws without underrun soles (categorized as sound) were $95.6 \%, 2.4 \%$ were mild to moderate and $2 \%$ were severe. $88.3 \%$ of the claws were without sole haemorrhage, $10.9 \%$ had mild to moderate, and $0.8 \%$ had a severe form of sole haemorrhage lesion score. Whereas, in non-lame, healthy cows, out of the 224 claws, $70 \%$ of the claws were free from any type of lesion, and $2.2 \%$ had at least two different types of lesions. $75.9 \%$ of claws were classified as sound in the heel horn erosion lesion score category, $95.5 \%$ in the overgrown sole lesion score category, $99.1 \%$ in the underrun sole lesion score category, and $97.3 \%$ in the sole haemorrhage lesion score category. $5.8 \%$ of the claws had a heel horn erosion lesion score classified as moderate. None of the claws from non-lame healthy cows had mild or severe types of lesion scores. 


\section{A. Singh et al.: Biotin-zinc supplementation in relation to hoof health and milk quality}

The average ST before the supplementation period was $9.5 \pm 0.32 \mathrm{~mm}$ in clinically lame cows, and $9.8 \pm 0.3 \mathrm{~mm}$ in non-lame healthy cows.

The average daily milk yield at the start of the study was $14.8 \pm 0.7 \mathrm{~kg}$ in clinically lame cows, and $16.8 \pm 0.8 \mathrm{~kg}$ in non-lame healthy cows. The average milk SCC $\left(\times 10^{3}\right.$ cells $/ \mathrm{mL}$ ) was $1247 \pm 447$ and $776 \pm 196$; fat (\%) $2.5 \pm 0.1$ and $2.9 \pm 0.2$; protein (\%) 3.6 \pm 0.1 and $3.5 \pm 0.1$; and lactose $4.8 \pm 0.1$ and $4.7 \pm 0.1$, respectively, in clinically lame and non-lame cows.

Effect of supplementation on $L S$ and BCS. The effect of supplementation of biotin and $\mathrm{ZnSO}_{4}$ on the LS in clinically lame and non-lame healthy cows is summarized in Table 2. Due to the supplementation, there was a significant improvement in the LS in the CLT cows (likelihood ratio Chi-square $=25.06, \mathrm{P}<0.001$ ). The proportion of CLT cows that were classified as sound increased to $64.7 \%$. On the other hand, the LS deteriorated in the $\mathrm{HC}$ cows at the end of the study (likelihood ratio Chi-square $=8.13, \mathrm{P}<0.01$ ); $38.5 \%$ cows became mildly to moderately lame. No significant change was seen in the HT and CLC cows in this study.

Table 2. The effect of supplementation of biotin and zinc sulphate on locomotion scores (LS) in clinically lame and non-lame healthy cows

\begin{tabular}{|c|c|c|c|c|c|}
\hline \multirow[b]{2}{*}{$\begin{array}{l}\text { Observation } \\
\text { recorded }\end{array}$} & \multirow[b]{2}{*}{$\begin{array}{l}\text { Classification } \\
\text { of LS }\end{array}$} & \multicolumn{2}{|c|}{ Treatment cows } & \multicolumn{2}{|c|}{ Control cows } \\
\hline & & $\begin{array}{c}\text { CLT } \\
\left(\mathrm{n}^{\#}=17\right)\end{array}$ & $\begin{array}{c}\text { HT } \\
(\mathrm{n}=15)\end{array}$ & $\begin{array}{c}\text { CLC } \\
(\mathrm{n}=14)\end{array}$ & $\begin{array}{c}\mathrm{HC} \\
(\mathrm{n}=13)\end{array}$ \\
\hline \multirow{3}{*}{$\begin{array}{l}\text { Before start of } \\
\text { study }\end{array}$} & Sound & $0^{\dagger}$ & 100 & 0 & 100 \\
\hline & Mild-Moderate & 64.7 & 0 & 50 & 0 \\
\hline & Severe & 35.3 & 0 & 50 & 0 \\
\hline \multirow{3}{*}{ At end of study } & Sound & 64.7 & 86.7 & 14.3 & 61.5 \\
\hline & Mild-Moderate & 35.3 & 13.3 & 64.3 & 38.5 \\
\hline & Severe & 0 & 0 & 21.4 & 0 \\
\hline \multicolumn{2}{|c|}{$\begin{array}{l}\text { Likelihood ratio Chi-square statics } \\
\text { P Value }\end{array}$} & $\begin{array}{l}25.06 \\
<0.001\end{array}$ & $\begin{array}{l}2.916 \\
\text { NS }\end{array}$ & $\begin{array}{l}4.669 \\
\text { NS }\end{array}$ & $\begin{array}{l}8.13 \\
<0.01\end{array}$ \\
\hline
\end{tabular}

${ }^{\#} \mathrm{n}$ represents the number of cows; $\uparrow$ Values are the percentage of the cows in each group; CLT: Clinically lame treatment; HT: Healthy treatment; CLC: Clinically lame control; HC: Healthy control; NS: Non-significant

Table 3 presents the results of the effect of supplementation of biotin and $\mathrm{ZnSO}_{4}$ on BCS in clinically lame and non-lame healthy cows. Although the proportion of supplemental cows (in the CLT and HT groups) with a BCS classified as good had increased at the end of the study period, the differences were found to be non-significant. On the other hand, BCS deteriorated non-significantly in the CLC cows. 
A. Singh et al.: Biotin-zinc supplementation in relation to hoof health and milk quality

Table 3. The effect of supplementation of biotin and zinc sulphate on body condition scores (BCS) in clinically lame and non-lame healthy cows

\begin{tabular}{|l|l|c|c|c|c|}
\hline \multirow{2}{*}{$\begin{array}{l}\text { Observation } \\
\text { recorded }\end{array}$} & \multirow{2}{*}{$\begin{array}{l}\text { Classification of } \\
\text { BCS }\end{array}$} & $\begin{array}{c}\text { Treatment cows } \\
\left(\mathrm{n}^{\#}=17\right)\end{array}$ & $\begin{array}{c}\text { HT } \\
(\mathrm{n}=15)\end{array}$ & $\begin{array}{c}\text { CLC } \\
(\mathrm{n}=14)\end{array}$ & $\begin{array}{c}\text { HC } \\
(\mathrm{n}=13)\end{array}$ \\
\cline { 2 - 6 } $\begin{array}{l}\text { Before start } \\
\text { of study }\end{array}$ & Low & $47^{\dagger}$ & 20 & 64.3 & 23.1 \\
\cline { 2 - 6 } & Good & 47.1 & 60 & 35.7 & 61.5 \\
\cline { 2 - 6 } & High & 5.9 & 20 & 0 & 15.4 \\
\hline \multirow{2}{*}{$\begin{array}{l}\text { At end of } \\
\text { study }\end{array}$} & Low & 23.5 & 13.3 & 71.4 & 15.4 \\
\cline { 2 - 6 } & Good & 58.8 & 66.7 & 28.6 & 61.5 \\
\cline { 2 - 6 } & High & 17.7 & 20 & 0 & 23.1 \\
\hline \multirow{2}{*}{$\begin{array}{l}\text { Likelihood ratio Chi-square statics } \\
\text { P Value }\end{array}$} & 2.628 & 0.254 & 0.164 & 0.403 \\
\hline
\end{tabular}

${ }^{*} \mathrm{n}$ represents the number of cows; $\dagger$ Values are the percentage of cows in each group; CLT: Clinically lame treatment; HT: Healthy treatment; CLC: Clinically lame control; HC: Healthy control; NS: Non-significant

Table 4. The effect of supplementation of biotin and zinc sulphate on heel horn erosion lesion scores in clinically lame and non-lame healthy cows

\begin{tabular}{|l|l|c|c|c|c|}
\hline \multirow{2}{*}{$\begin{array}{l}\text { Observation } \\
\text { recorded }\end{array}$} & $\begin{array}{l}\text { Classification of } \\
\text { lesion score }\end{array}$ & $\begin{array}{c}\text { Treatment cows } \\
\left(\mathrm{n}^{\#}=136\right)\end{array}$ & $\begin{array}{c}\text { HT } \\
(\mathrm{n}=120)\end{array}$ & $\begin{array}{c}\text { CLC } \\
(\mathrm{n}=112)\end{array}$ & $\begin{array}{c}\text { HC } \\
(\mathrm{n}=104)\end{array}$ \\
\cline { 2 - 6 } $\begin{array}{l}\text { Before start } \\
\text { of study }\end{array}$ & Absent & $73.5^{\dagger}$ & 70.8 & 61.6 & 81.7 \\
\cline { 2 - 6 } & Mild to Moderate & 22.1 & 29.2 & 26.8 & 18.3 \\
\cline { 2 - 6 } & Severe & 4.4 & 0 & 11.6 & 0 \\
\hline \multirow{2}{*}{$\begin{array}{l}\text { At end of } \\
\text { study }\end{array}$} & Absent & 80.1 & 71.7 & 68.7 & 61.5 \\
\cline { 2 - 6 } & Mild to Moderate & 19.9 & 28.3 & 25.9 & 34.6 \\
\cline { 2 - 6 } & Severe & 0 & 0 & 5.4 & 3.9 \\
\hline \multicolumn{2}{|l|}{$\begin{array}{l}\text { Likelihood ratio Chi-square statics } \\
\text { P Value }\end{array}$} & 8.863 & 0.02 & 3.096 & 13.856 \\
\hline
\end{tabular}

${ }^{\#} \mathrm{n}$ represents the number of claws; $\uparrow$ Values are the percentage of claws in each group; CLT: Clinical lame treatment; HT: Healthy treatment; CLC: Clinically lame control; HC: Healthy control; NS: Non-significant

Effect of supplementation on claw lesions. The proportion of claws with heel horn erosion lesion scores categorized as mild to severe in the supplemental clinically lame cows (CLT) decreased significantly over the study period (Likelihood ratio Chi-square $=8.863$, $\mathrm{P}<0.05)$ (Table 4). In contrast, the proportion of mild to severe lesion scores increased significantly in the non-lame $\mathrm{HC}$ cows (Likelihood ratio Chi-square $=13.856, \mathrm{P}<0.001$ ).

As shown in Table 5, the proportion of claws with no overgrown sole lesion score (i.e. absent) increased from 88.2 to $100 \%$ and mild to moderate scores decreased from 
A. Singh et al.: Biotin-zinc supplementation in relation to hoof health and milk quality

11.8 to $0 \%$ in the CLT cows (Likelihood ratio Chi-square $=8.863, \mathrm{P}<0.05$ ). No significant change in the lesion score was observed in cows belonging to other groups.

Table 5. The effect of supplementation of biotin and zinc sulphate on overgrown sole lesion scores in clinically lame and non-lame healthy cows

\begin{tabular}{|c|c|c|c|c|c|}
\hline \multirow[b]{2}{*}{$\begin{array}{l}\text { Observation } \\
\text { recorded }\end{array}$} & \multirow[b]{2}{*}{$\begin{array}{l}\text { Classification of } \\
\text { lesion score }\end{array}$} & \multicolumn{2}{|c|}{ Treatment cows } & \multicolumn{2}{|c|}{ Control cows } \\
\hline & & $\begin{array}{c}\text { CLT } \\
\left(\mathrm{n}^{\#}=136\right)\end{array}$ & $\begin{array}{c}\text { HT } \\
(\mathrm{n}=120)\end{array}$ & $\begin{array}{c}\text { CLC } \\
(\mathrm{n}=112)\end{array}$ & $\begin{array}{c}\mathrm{HC} \\
(\mathrm{n}=104)\end{array}$ \\
\hline \multirow{3}{*}{ Before start of study } & Absent & $88.2^{\dagger}$ & 96.7 & 90.2 & 94.2 \\
\hline & Mild to Moderate & 11.8 & 3.3 & 9.8 & 5.8 \\
\hline & Severe & 0 & 0 & 0 & 0 \\
\hline \multirow{3}{*}{ At end of study } & Absent & 100 & 98.3 & 94.6 & 96.2 \\
\hline & Mild to Moderate & 0 & 1.7 & 5.4 & 3.8 \\
\hline & Severe & 0 & 0 & 0 & 0 \\
\hline \multicolumn{2}{|c|}{$\begin{array}{l}\text { Likelihood ratio Chi-square statics } \\
\text { P Value }\end{array}$} & $\begin{array}{l}23.181 \\
<0.001\end{array}$ & $\begin{array}{l}0.697 \\
\text { NS }\end{array}$ & $\begin{array}{l}1.613 \\
\text { NS }\end{array}$ & $\begin{array}{l}0.423 \\
\text { NS }\end{array}$ \\
\hline
\end{tabular}

${ }^{\#} \mathrm{n}$ represents the number of claws; $\uparrow$ Values are the percentage of claws in each group; CLT: Clinically lame treatment; HT: Healthy treatment; CLC: Clinically lame control; HC: Healthy control; NS: Non-significant

Table 6. The effect of supplementation of biotin and zinc sulphate on underrun lesion scores in clinically lame and non-lame healthy cows

\begin{tabular}{|l|l|c|c|c|c|}
\hline \multirow{2}{*}{$\begin{array}{l}\text { Observation } \\
\text { recorded }\end{array}$} & \multicolumn{2}{|c|}{ Treatment cows } & \multicolumn{2}{c|}{ Control cows } \\
\cline { 2 - 6 } & $\begin{array}{l}\text { Classification of } \\
\text { lesion score }\end{array}$ & $\begin{array}{c}\text { CLT } \\
\left(\mathrm{n}^{\#}=136\right)\end{array}$ & $\begin{array}{c}\text { HT } \\
(\mathrm{n}=120)\end{array}$ & $\begin{array}{c}\text { CLC } \\
(\mathrm{n}=112)\end{array}$ & $\begin{array}{c}\text { HC } \\
(\mathrm{n}=104)\end{array}$ \\
\hline \multirow{3}{*}{ Before start of study } & $95.6^{\dagger}$ & $\frac{99.2}{9}$ & 95.5 & 99.0 \\
\cline { 2 - 6 } & Absent & 2.2 & 0.8 & 2.7 & 1.0 \\
\cline { 2 - 6 } & Mild to Moderate & 2.2 & 0 & 1.8 & 0 \\
\cline { 2 - 6 } At end of study & Severe & 95.6 & 92.5 & 95.5 & 98.1 \\
\cline { 2 - 6 } & Absent & 2.9 & 7.5 & 3.6 & 1.9 \\
\cline { 2 - 6 } & Mild to Moderate & 1.5 & 0 & 0.9 & 0 \\
\cline { 2 - 6 } & Severe & 0.345 & 7.64 & 0.483 & 0.345 \\
\hline \multirow{2}{*}{$\begin{array}{l}\text { Likelihood ratio Chi-square statics, } \\
\text { P Value }\end{array}$} & $\mathrm{NS}$ & $<0.01$ & $\mathrm{NS}$ & $\mathrm{NS}$ \\
\hline
\end{tabular}

\# $\mathrm{n}$ represents the number of claws; $\dagger$ Values are the percentage of claws in each group; CLT: Clinically lame treatment; HT: Healthy treatment; CLC: Clinically lame control; HC: Healthy control; NS: Non-significant

Table 6 describes the effect of supplementation on the percentages of underrun sole lesion scores in treatment and control cows. Cows in the HT group had significantly higher claws with mild to moderate $(7.5 \%)$ underrun sole lesion scores at the end of the study (Likelihood ratio Chi-square $=7.64, \mathrm{P}<0.01$ ). The other cow groups did not show any significant change in underrun sole lesion scores at the end of the study. 


\section{A. Singh et al.: Biotin-zinc supplementation in relation to hoof health and milk quality}

The effect of supplementation of biotin and $\mathrm{ZnSO}_{4}$ on sole hemorrhage lesion scores in the treatment and control groups is shown in Table 7. Overall, there was an improvement in the sole hemorrhage lesion score in all the groups, however, significant changes (Likelihood ratio Chi-square $=9.335, \mathrm{P}<0.01$ ) were only observed in CLT cows in which the proportion of mild to moderate scores decreased from 12.5 to $2.9 \%$.

Table 7. The effect of supplementation of biotin and zinc sulphate on sole hemorrhage lesion scores in clinically lame and non-lame healthy cows

\begin{tabular}{|c|c|c|c|c|c|}
\hline \multirow[b]{2}{*}{$\begin{array}{l}\text { Observation } \\
\text { recorded }\end{array}$} & \multirow[b]{2}{*}{$\begin{array}{l}\text { Classification of } \\
\text { lesion score }\end{array}$} & \multicolumn{2}{|c|}{ Treatment cows } & \multicolumn{2}{|c|}{ Control cows } \\
\hline & & $\begin{array}{c}\text { CLT } \\
\left(\mathrm{n}^{\#}=136\right)\end{array}$ & $\begin{array}{c}\text { HT } \\
(\mathrm{n}=120)\end{array}$ & $\begin{array}{c}\text { CLC } \\
(\mathrm{n}=112)\end{array}$ & $\begin{array}{c}\mathrm{HC} \\
(\mathrm{n}=104)\end{array}$ \\
\hline \multirow{3}{*}{ Before start of study } & Absent & $87.5^{\dagger}$ & 98.3 & 89.3 & 94.2 \\
\hline & Mild to Moderate & 12.5 & 1.7 & 9.8 & 5.8 \\
\hline & Severe & 0 & 0 & 0.9 & 0 \\
\hline \multirow{3}{*}{ At end of study } & Absent & 97.1 & 99.2 & 93.8 & 98.1 \\
\hline & Mild to Moderate & 2.9 & 0.8 & 5.3 & 1.9 \\
\hline & Severe & 0 & 0 & 0.9 & 0 \\
\hline \multicolumn{2}{|c|}{$\begin{array}{l}\text { Likelihood ratio Chi-square statics } \\
\text { P Value }\end{array}$} & $\begin{array}{l}9.335 \\
<0.01\end{array}$ & $\begin{array}{c}0.344 \\
\text { NS }\end{array}$ & $\begin{array}{c}1.615 \\
\text { NS }\end{array}$ & $\begin{array}{c}2.173 \\
\text { NS }\end{array}$ \\
\hline
\end{tabular}

${ }^{\#} \mathrm{n}$ represents the number of claws; $\uparrow$ Values are the percentage of claws in each group; CLT: Clinically lame treatment; HT: Healthy treatment; CLC: Clinically lame control; HC: Healthy control; NS: Non-significant

Effect of supplementation on ST. Sole thickness increased significantly $(\mathrm{P}<0.05)$ in the clinically lame cows supplemented with biotin and zinc (Table 8 ). On the contrary, the ST decreased significantly $(\mathrm{P}<0.05)$ in the CLC cows. There was a non-significant difference in the pre- and post-treatment values of the ST in healthy supplemented and control cows.

Table 8. The effect of supplementation of biotin and zinc sulphate on sole thickness (ST) in clinically lame and non-lame healthy cows

\begin{tabular}{|c|c|c|c|c|c|}
\hline \multirow[b]{2}{*}{ Parameter } & \multirow[b]{2}{*}{ Observation recorded } & \multicolumn{2}{|c|}{ Treatment cows } & \multicolumn{2}{|c|}{ Control cows } \\
\hline & & $\operatorname{CLT}\left(\mathrm{n}^{\#}=36\right)$ & $\mathrm{HT}(\mathrm{n}=28)$ & $\operatorname{CLC}(\mathrm{n}=20)$ & $\mathrm{HC}(\mathrm{n}=12)$ \\
\hline \multirow{3}{*}{$\mathrm{ST}(\mathrm{mm})$} & Before start of study & $9.0^{\mathrm{a}} \pm 0.39^{\dagger}$ & $10.3^{\mathrm{a}} \pm 0.4$ & $10.5^{\mathrm{a}} \pm 0.5$ & $8.6^{\mathrm{a}} \pm 0.3$ \\
\hline & At end of study & $10.0^{\mathrm{b}} \pm 0.5$ & $9.7^{\mathrm{a}} \pm 0.38$ & $9.4^{b} \pm 0.6$ & $8.7^{\mathrm{a}} \pm 0.8$ \\
\hline & P Value & $<0.05$ & NS & $<0.05$ & $\mathrm{NS}$ \\
\hline
\end{tabular}

\# $\mathrm{n}$ represents the number of claws in hind feet; $\dagger$ Values are mean $\pm \mathrm{SE}$; CLT: Clinically lame treatment; HT: Healthy treatment; CLC: Clinically lame control; HC: Healthy control; NS: Non-significant; In columns, for ST, mean values with different superscripts differ significantly 
A. Singh et al.: Biotin-zinc supplementation in relation to hoof health and milk quality

Effect of supplementation on milk parameters. Table 9 shows the effect of supplementation of biotin and $\mathrm{ZnSO}_{4}$ on milk yield and milk quality parameters in treatment and control cows. In supplemental clinically lame cows, the average milk yield increased from $15.4 \mathrm{~kg}$ to $20 \mathrm{~kg}(\mathrm{P}<0.001)$ and fat content increased from 2.6 to $3.5 \%$ $(\mathrm{P}<0.05)$, whereas the average $\log _{10} \mathrm{SCC}$ (absolute SCC) decreased from $5.6\left(1120 \times 10^{3}\right)$ cells $/ \mathrm{mL}$ to $5.1\left(213 \times 10^{3}\right)$ cells $/ \mathrm{mL}(\mathrm{P}<0.05)$. There was a significant decline in the average milk SCC $(\mathrm{P}<0.05)$ in the HT and protein content $(\mathrm{P}=0.05)$ in the CLC. The mean values of other milk parameters did not vary significantly between the pre- and post-study period for the treatment and control cows.

Table 9. The effect of supplementation of biotin and zinc sulphate on milk yield and composition in clinically lame and non-lame healthy cows

\begin{tabular}{|c|c|c|c|c|c|}
\hline \multirow[b]{2}{*}{ Parameter } & \multirow[b]{2}{*}{$\begin{array}{l}\text { Observation } \\
\text { recorded }\end{array}$} & \multicolumn{2}{|c|}{ Treatment cows } & \multicolumn{2}{|c|}{ Control cows } \\
\hline & & $\begin{array}{c}\text { CLT } \\
\left(\mathrm{n}^{\#}=17\right)\end{array}$ & $\begin{array}{c}\text { HT } \\
(\mathrm{n}=15)\end{array}$ & $\begin{array}{c}\text { CLC } \\
(\mathrm{n}=14)\end{array}$ & $\begin{array}{c}\mathrm{HC} \\
(\mathrm{n}=13)\end{array}$ \\
\hline \multirow{3}{*}{ Milk yield (Kg) } & $\begin{array}{l}\text { Before start of } \\
\text { study }\end{array}$ & $15.4^{\mathrm{a}} \pm 0.86^{\dagger}$ & $17.1 \pm 0.98$ & $14.1 \pm 1.27$ & $16.3 \pm 1.3$ \\
\hline & At end of study & $19.8^{b} \pm 1.46$ & $18.8 \pm 1.85$ & $13.9 \pm 1.8$ & $14.8 \pm 2.15$ \\
\hline & P Value & $<0.001$ & NS & $\mathrm{NS}$ & NS \\
\hline \multirow{3}{*}{$\begin{array}{l}\log _{10} \mathrm{SCC} \\
(\text { cells } / \mathrm{mL}) \\
\left(\times 10^{3} \text { cells } / \mathrm{mL}\right)\end{array}$} & $\begin{array}{l}\text { Before start of } \\
\text { study }\end{array}$ & $\begin{array}{r}5.6^{a} \pm 0.15 \\
(1120 \pm 564) \\
\end{array}$ & $\begin{array}{r}5.5^{\mathrm{a}} \pm 0.13 \\
(601 \pm 125) \\
\end{array}$ & $\begin{array}{r}5.6 \pm 0.18 \\
(1400 \pm 735) \\
\end{array}$ & $\begin{array}{r}5.5 \pm 0.19 \\
(977 \pm 399) \\
\end{array}$ \\
\hline & At end of study & $\begin{array}{l}5.1^{\mathrm{b}} \pm 0.12 \\
(213 \pm 59)\end{array}$ & $\begin{array}{r}4.9^{\mathrm{b}} \pm 0.22 \\
(307 \pm 102)\end{array}$ & $\begin{array}{r}5.7 \pm 0.23 \\
(2461 \pm 978)\end{array}$ & $\begin{array}{c}5.8 \pm 0.25 \\
(2478 \pm 1012)\end{array}$ \\
\hline & P Value & $<0.05$ & $<0.05$ & NS & NS \\
\hline \multirow{3}{*}{ Fat $(\%)$} & $\begin{array}{l}\text { Before start of } \\
\text { study }\end{array}$ & $2.6^{\mathrm{a}} \pm 0.2$ & $3.1 \pm 0.31$ & $2.4 \pm 0.19$ & $2.74 \pm 0.39$ \\
\hline & At end of study & $3.5^{\mathrm{b}} \pm 0.24$ & $3.1 \pm 0.33$ & $2.6 \pm 0.35$ & $2.7 \pm 0.4$ \\
\hline & P Value & $<0.05$ & $\mathrm{NS}$ & $\mathrm{NS}$ & NS \\
\hline \multirow{3}{*}{ Protein $(\%)$} & $\begin{array}{l}\text { Before start of } \\
\text { study }\end{array}$ & $3.5 \pm 0.1$ & $3.6 \pm 0.07$ & $3.7^{\mathrm{a}} \pm 0.1$ & $3.6 \pm 0.12$ \\
\hline & At end of study & $3.6 \pm 0.08$ & $3.5 \pm 0.07$ & $3.4^{b} \pm 0.08$ & $3.4 \pm 0.08$ \\
\hline & P Value & NS & NS & 0.05 & NS \\
\hline \multirow{3}{*}{ Lactose (\%) } & $\begin{array}{l}\text { Before start of } \\
\text { study }\end{array}$ & $4.7 \pm 0.09$ & $4.7 \pm 0.1$ & $4.9 \pm 0.12$ & $4.7 \pm 0.06$ \\
\hline & At end of study & $4.8 \pm 0.06$ & $4.9 \pm 0.09$ & $4.8 \pm 0.08$ & $4.7 \pm 0.11$ \\
\hline & P Value & NS & $\mathrm{NS}$ & NS & NS \\
\hline
\end{tabular}

${ }^{\#} \mathrm{n}$ represents the number of cows; †Values are mean $\pm \mathrm{SE}$; CLT: Clinically lame treatment; HT: Healthy treatment; CLC: Clinically lame control; HC: Healthy control; NS: Non-significant; In columns, for different milk parameters, mean values with different superscripts differ significantly 


\section{A. Singh et al.: Biotin-zinc supplementation in relation to hoof health and milk quality}

\section{Discussion}

Locomotion and body condition scores. Clinically lame cows supplemented daily with $1 \mathrm{~g}$ of $2 \%$ biotin and $4 \mathrm{~g}$ of $\mathrm{ZnSO}_{4}$ for a period of 4 months showed a significant improvement in the LS. On the other hand, about $40 \%$ of the HC cows developed a mild to moderate form of LS. A previous study reported a non-significant improvement in the LS in cows after supplementation with biotin (RANDHAWA et al., 2008). The significant improvement in the gait of lame cows in our study could be the result of the concurrent supplementation of biotin and $\mathrm{ZnSO}_{4}$. Biotin dependent enzymes are directly involved in the synthesis and improvement of the quality of the fatty acid profile of hoof horn tissue (OFFER and LOGUE, 1998; WEISS and ZIMMERLY, 2000), which in turn, improves membrane structure and function. Biotin is also essential for the formation of complex lipid molecules in the intracellular cementing substance (MULLING et al., 1999), which improves the quality of ceramides, resulting in improved horn quality (RANDHAWA et al., 2008). Similarly, zinc was identified as one of the key minerals in the keratinization process (TOMLINSON et al., 2004), and greater concentrations of $\mathrm{Zn}$ are found in the harder keratin of the hoof wall compared with the softer keratin in the heel (BAGGOTT et al., 1988). The increased bioavailability of trace minerals such as zinc could lead to improved keratinized tissues in the claw, ultimately reducing lameness incidence in cows (TOMLINSON et al., 2004). The combined feeding of biotin and Zn might have a synergistic effect on the correction of lameness in dairy cows.

Although non-significant, supplementation of biotin and $\mathrm{Zn}$ also improved BCS in both clinically lame and healthy cows. In lame cows, the pain associated with the severe claw lesions may decrease standing time, which in turn might result in inappropriate feeding and poor BCS in the affected cows (GOMEZ and COOK, 2010). Our results are also supported by GREEN et al. (2014) and SINGH et al. (2018) who showed a positive relationship between the LS and low BCS. However, other studies did not confirm improvement in body weight or BCS in dairy cows supplemented with either Zn (NOCEK et al., 2006) or biotin (MAJEE et al., 2003). Supplementation of biotin and $\mathrm{ZnSO}_{4}$ might have improved the BCS of the lame cows due to the improvement in their gait and better feeding.

Claw lesions. Heel horn erosions were the most prevalent claw lesions in this study. About $32 \%$ of the claws in clinically lame cows and $6 \%$ of the claws in non-lame cows had mild to severe forms of heel horn erosion scores. There was a considerable reduction in the severity of the heel horn erosion scores in supplemental lame cows, whereas, the reverse was noted in healthy non-supplemental cows. Our finding of reduced heel horn erosion scores in supplemental lame cows is in agreement with the results of VOIGT et al. (2000), who also reported a significant reduction in heel erosions after supplementation of biotin. This favorable effect in the supplemental cows could be due to the improved fatty acid profile in the heels (WEISS and ZIMMERLY, 2000) and appropriate maturation 
of keratins (SMART and CYMBALUK, 1997). The functional integrity of the hoof horn essentially depends on the keratinization process which is dependent upon various bioactive molecules, hormones and nutrients, regulation and control of differentiation, and nutrient flow to the epidermal cells. Optimum nutrient supply to the keratinizing epidermal cells leads to horn production of superior quality and decreased susceptibility to chemical, physical, or microbial damage from the environment (TOMLINSON et al., 2004). BERGSTEN et al. (2003) found that biotin induced resistance in the epidermis, and decreased the incidence of heel erosions. However, MIDLA et al. (1998) found no significant effect of the biotin supplementation on heel erosions.

We observed a significant reduction in the lesion score related to overgrown soles in the supplemental lame cows at the end of the study period. Increased compactness of the hoof epidermis after combined supplementation of biotin and $\mathrm{ZnSO}_{4}$ was evident as no recurrence of overgrown sole was seen after the trial period (RANDHAWA et al., 2008). Zinc also participated in the structural formation of the hooves (COUSINS, 1996). It regulates calmodulin, and then activated calmodulin binds with the calcium and carries it into the cytosol of the cell. It is important for the development of keratinocyte because calcium activates epidermal transglutaminase, which is involved in the initiation and regulation of the terminal differentiation of the epidermal cells (TOMLINSON et al., 2004). The decrease in the severity of sole hemorrhages in this study was also an important factor for the reduction of overgrown soles because of the reduced irritation that is responsible for hyperkeratotic changes in the sole bulb area.

We could not find any association between supplementation of biotin and $\mathrm{Zn}$ and the correction of underrun lesion scores in CLT cows. Instead there was a rise in the lesion score in the non-lame healthy cows supplemented with biotin and $\mathrm{Zn}$. Our results corroborate with the findings of RANDHAWA et al. (2008), who also found an increase in the underrun sole lesion scores in cows supplemented with biotin.

There was a significant decline in the sole hemorrhage lesion score in supplemental lame cows, which corroborates with the results of BERGSTEN et al. (2003). A more resilient hoof capsule and better attachment of the pedal bone within it, together with intact hoof cushions, might explain the lower incidence of sole hemorrhages in supplemented groups (BERGSTEN et al., 2003). However, MIDLA et al. (1998) noticed a better effect of biotin supplementation on white line lesions in comparison with sole hemorrhages.

Sole thickness. The average ST measured in this study was similar to that reported earlier (VAN AMSTEL et al., 2016). Sole thickness was only measured on the back claws since it has been shown that the sole horns of the back feet wear more quickly than those of the front feet, and are thus more prone to increased wear and resulting lameness (VAN AMSTEL et al., 2004). Overall, at the beginning of the trial the clinically lame cows had slightly thinner soles as compared with the healthy cows. There was an increase in the thickness of the soles at the end of the trial in the clinically lame supplemented cows. On 


\section{A. Singh et al.: Biotin-zinc supplementation in relation to hoof health and milk quality}

the other hand, the ST decreased in clinically lame non-supplemented cows. Probably, this is the first report depicting the effect of supplemental biotin and $\mathrm{ZnSO}_{4}$ on the ST in clinically lame dairy cows. The thickness of the sole should be enough to protect the corium, a structure lying just under the sole horn, against the development of lesions, such as a subsolar abscess (SHEARER and VAN AMSTEL, 2009). The results of our study indicate the possible protective effect of supplementation (versus non-supplementation) against excessive wear of the sole horn in lame cows. The ST might have increased due to improved keratinization, and the better quantity and quality of lipids in the intracellular cementing substance in the hooves. Also, improved ceramides, along with upgraded intracellular cementing material had a substantial effect on the ST. More resilient hooves might have undergone less grinding of the sole surface due to wear. Cows which were already lame had a tendency for increased wear and slightly thinner soles.

Milk parameters. Milk yield was lower but milk SCC was higher in clinically lame cows than non-lame healthy cows at the start of the study. There is a large number of studies demonstrating the negative impact of lameness on milk production (WARNICK et al., 2001; GREEN et al., 2002) and milk quality (JUAREZ et al., 2003; RUKOL, 2012). Further, the lame cows supplemented with biotin and $\mathrm{Zn}$ showed a significant rise in their milk yield. Also, there was an improvement in milk quality in terms of both SCC and fat percentage in the clinically lame cows, and SCC in the non-lame healthy cows supplemented with biotin and $\mathrm{Zn}$. We also observed decreased milk protein content in non-supplemented clinically lame cows. Other studies have suggested that supplementing $\mathrm{Zn}$ (either inorganic or organic) not only reduces SCC but also improves milk yield and composition (KELLOGG et al., 2004; COPE et al., 2009). Our results are also consistent with those of KINAL et al. (2011) who also observed that cows receiving biotin and $\mathrm{Zn}$ (as methionine) supplementation had lower milk SCC. ARVIDSON (2000) suggested lameness as a precipitating factor for increased SCC and mastitis occurrence in dairy cows. This could be attributed to increased lying time in lame cows that might have exposed their udders to various intra-mammary infections due to the closer proximity to underfoot slurry. Supplementation of biotin and $\mathrm{ZnSO}_{4}$ might have a positive influence on udder health as there was a decline in the milk SCC attributed to the improved quality of the keratin web inside the teat canal, which acts as a physical barrier for the udder against various intra-mammary infections.

\section{Conclusions}

We conclude that supplementation of dairy cows with biotin and $\mathrm{ZnSO}_{4}$ might have a synergistic and protective effect on the horn quality, as it not only reduced the severity of lameness and claw lesions, but also prevented their occurrence. Moreover, the supplemental cows also showed improvement in terms of milk quantity and quality as compared with the non-supplemental cows. 
A. Singh et al.: Biotin-zinc supplementation in relation to hoof health and milk quality

\section{Conflicts of interest}

The authors do not have any conflicts of interest to declare.

Supplementary material: Claw lesions observed in lactating dairy cows

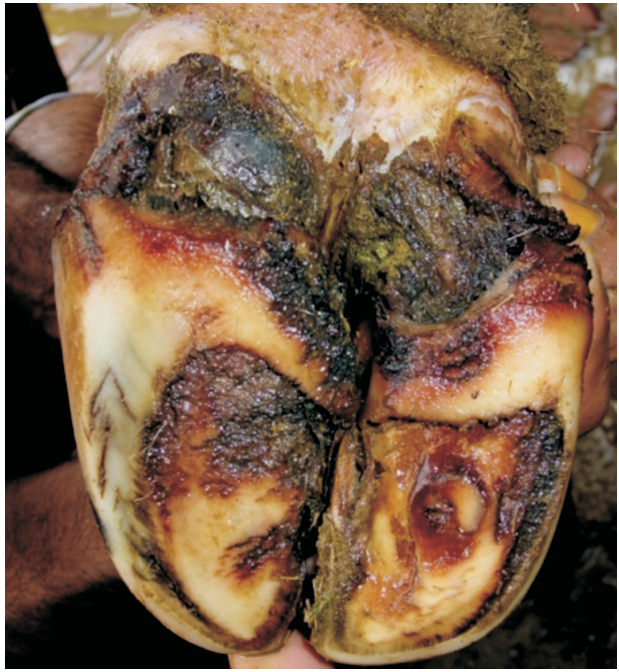

Heel erosions

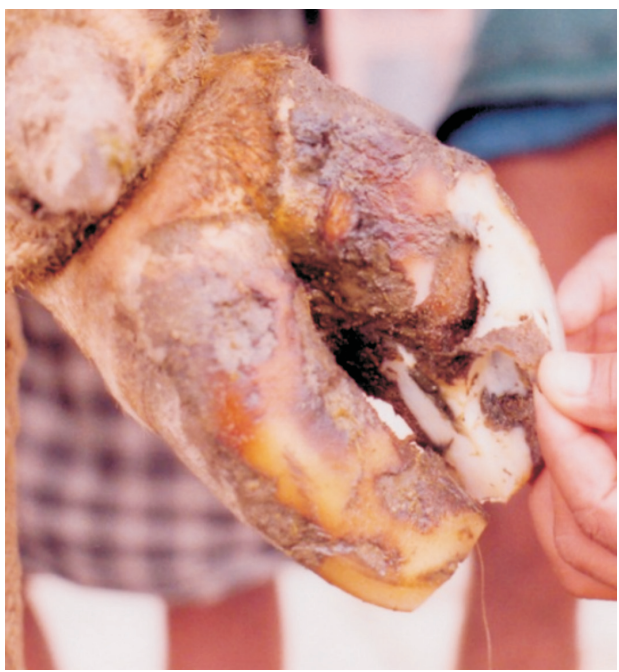

Underrun sole

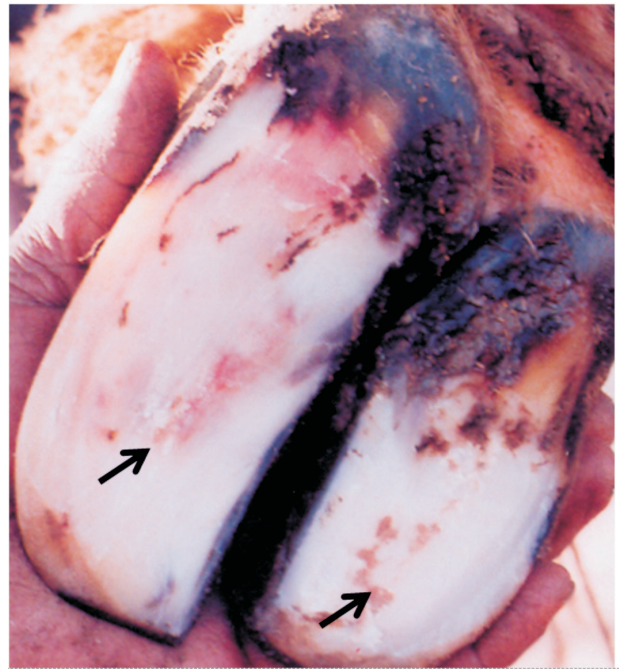

Sole haemorrhage

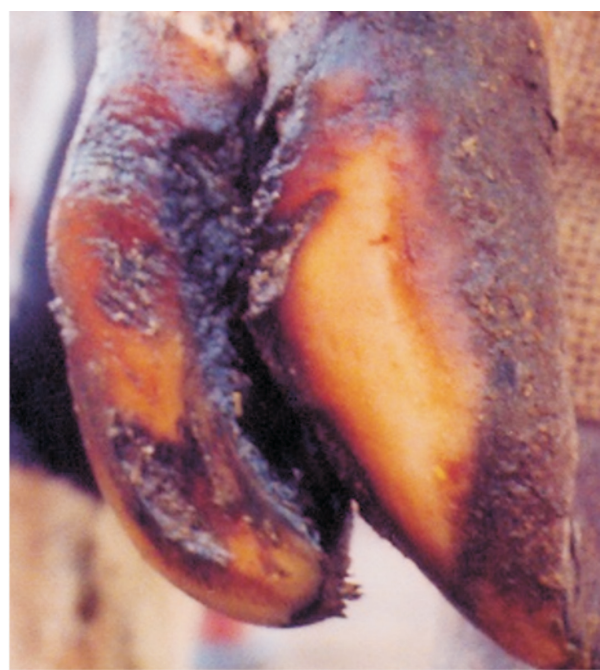

Overgrown sole 
A. Singh et al.: Biotin-zinc supplementation in relation to hoof health and milk quality

\section{References}

ARVIDSON, A. K. (2000): Environmental and management factors associated with the incidence of clinical mastitis in high yielding dairy herds with a low incidence of subclinical mastitis (In Swedish), Graduate report 136, Department of Animal Nutrition and Management, Swedish University of Agricultural Science, Uppsala, Sweden.

BAGGOTT, D. G., K. J. BUNCH, K. R. GILL (1988): Variations in some inorganic components and physical properties of claw keratin associated with claw disease in the British Friesian cow. Br. Vet. J. 144, 534-542.

DOI: 10.1016/0007-1935(88)90023-1

BALlANTINE, H. T., M. T. SOCHA, D. J. TOMLINSON, A. B. JOHNSON, A. S. FIELDING, J. K. SHEARER, S. R. VAN AMSTEL (2002): Effect of feeding complexed zinc, manganese, copper and cobalt to late gestation and lactating dairy cows on claw integrity, reproduction and lactation performance. Prof. Anim. Sci. 18, 211.

DOI: $10.15232 / \mathrm{S} 1080-7446(15) 31524-2$

BARKER, Z. E., K. A. LEACH, H. R. WHAY, N. J. BELL, D. C. MAIN (2010): Assessment of lameness prevalence and associated risk factors in dairy herds in England and Wales. J. Dairy Sci. 93, 932-941.

DOI: $10.3168 /$ jds.2009-2309

BERGSTEN, C., P. R. GREENOUGH, J. M. GAY, W. M. SEYMOUR, C. C. GAY (2003): Effects of biotin supplementation on performance and claw lesions on a commercial dairy farm. J. Dairy Sci. 86, 3953-3962.

DOI: $10.3168 /$ jds.S0022-0302(03)74005-3

BERGSTEN, C., J. HULGREN, A. HILLSTÖM (2006): Using a footbath with copper sulfate or peracetic acid foam for the control of digital dermatitis and heel horn erosion in a dairy herd. In: Proceedings of the 14th International symposium and $6^{\text {th }}$ Conference on lameness in ruminants, Uruguay, pp. 61-62.

BOOTH, C. J., L. D. WARNICK, Y. T. GROHN, D. O. MAIZON, C. L. GUARD, D. JANSSEN (2004): Effect of lameness on culling in dairy cows. J. Dairy Sci. 87, 4115-4122.

DOI: $10.3168 /$ jds.S0022-0302(04)73554-7

BRUIJNIS, M. R. N., B. BEERDA, H. HOGEVEEN, E. N. STASSEN (2012): Assessing the welfare impact of foot disorders in dairy cattle by a modeling approach. Anim. 6, 962-970.

DOI: $10.1017 / \mathrm{S} 1751731111002606$

CAPION, N., C. ENEVOLDSEN, S. M. THAMSBORG (2008): Prevalence of foot lesions in Danish Holstein cows. Vet. Rec. 163, 80-86.

DOI: $10.1136 /$ vr.163.3.80

COPE, C. M., A. M. MACKENZIE, D. WILDE, L. A. SINCLAIR (2009): Effects of level and form of dietary zinc on dairy cow performance and health. J. Dairy Sci. 92, 2128-2135.

DOI: $10.3168 /$ jds.2008-1232

Vet. arhiv 89 (6), 799-820, 2019 
A. Singh et al.: Biotin-zinc supplementation in relation to hoof health and milk quality

COUSINS, R. J. (1996): Zinc. In: Present Knowledge in Nutrition, (Ziegler, E. E., L. J. Filer Jr. Eds.). $7^{\text {th }}$ ed., I.L.S.I. Press, Washington, pp. 293.

CRAMER, G., K. D. LISSEMORE, C. L. GUARD, K. E. LESLIE, D. F. KELTON (2009): The association between foot lesions and culling risk in Ontario Holstein cows. J. Dairy Sci. 92, 2572-2579.

DOI: $10.3168 /$ jds.2008-1532

DRENDEL, T. R., P. C. HOFFMAN, N. ST-PIERRE, M. T. SOCHA, D. J. TOMLINSON, T. L. WARD (2005): Effects of feeding zinc, manganese, and copper amino acid complexes and cobalt glucoheptonate to dairy replacement heifers on claw disorders. Prof. Anim. Sci. 21, 217-224.

DOI: $10.15232 / \mathrm{S} 1080-7446(15) 31206-7$

FERGUSON, J. D., D. T. GALIGAN, N. THOMSEN (1994): Principal disruptors of body condition score in Holstein cows. J. Dairy Sci. 77, 2695-2703.

DOI: $10.3168 /$ jds.S0022-0302(94)77212-X

FRITSCHE, A., G. A. MATHIS, F. R. ALTHAUS (1991): Pharmacological effects of biotin on epidermal cells. Schweiz. Arch. Tierheilkd. 133, 277-283 (in German).

GHOLAM, R. N., A. HAMID, M. EHSAN, Z. DAVOOD, S. M. SEYYED, S. EHSAN (2013): Top-dressing of the different feed additives is effective to prevent lameness and to increase feedlot cattle performance during a short-term period. J. Appl. Anim. Res. 41, 263-268.

DOI: $10.1080 / 09712119.2012 .742441$

GOMEZ, A., N. B. COOK (2010): Time budgets of lactating dairy cattle in commercial freestall herds. J. Dairy Sci. 93, 5772-5781.

DOI: $10.3168 /$ jds.2010-3436

GREEN, L. E., V. J. HEDGES, Y. H. SCHUKKEN, R. W. BLOWEY, A. J. PACKINGTON (2002): The impact of clinical lameness on the milk yield of dairy cows. J. Dairy Sci. 85, 2250-2256.

DOI: $10.3168 /$ jds.S0022-0302(02)74304-X

GREEN, L. E., J. N. HUXLEY, C. BANKS, M. J. GREEN (2014): Temporal associations between low body condition, lameness and milk yield in a UK dairy herd. Prev. Vet. Med. 113, 63-71. DOI: 10.1016/j.prevetmed.2013.10.009

HEDGES, V. J., R. W. BLOWEY, A. J. PACKINGTON, C. J. O'CALLAGHAN, L. E. GREEN (2001): A longitudinal field trial of the effect of biotin on lameness in dairy cows. J. Dairy Sci. 84, 1969-1975.

DOI: $10.3168 /$ jds.S0022-0302(01)74639-5

HIGUCHI, H., H. NAGAHATA (2001): Relationship between serum biotin concentration and moisture content of the sole horn in cows with clinical laminitis or sound hooves. Vet. Rec. 148, 209-210.

DOI: $10.1136 /$ vr.148.7.209 


\section{A. Singh et al.: Biotin-zinc supplementation in relation to hoof health and milk quality}

JUAREZ, S. T., P. H. ROBINSON, E. J. DEPETERS, E. O. PRICE (2003): Impact of lameness on behaviour and productivity of lactating Holstein cows. Appl. Anim. Behav. Sci. 83, 1-14.

DOI: 10.1016/S0168-1591(03)00107-2

KELLOGG, D. W., D. J. TOMLINSON, M. T. SOCHA, A. B. JOHNSON (2004): Effect of feeding zinc methionine complex on milk production and somatic cell count of dairy cattle: Twelvetrial summary. Prof. Anim. Sci. 20, 295-301.

DOI: $10.15232 / \mathrm{S} 1080-7446(15) 31318-8$

KESSLER, J., I. MOREL, F. A. DUFEY, A. GUTZWILLER, A. STERN, H. GEYES (2003): Effect of organic zinc sources on performance, zinc status, and carcass, meat, and claw quality in fattening bulls. Livest. Prod. Sci. 81, 161-171.

DOI: 10.1016/S0301-6226(02)00262-2

KINAL, S., A. KORNIEWICZ, D. JAMROZ, R. ZIEMINSKI, M. SLUPEZYNSKA (2005): Dietary effects of zinc, copper and manganese chelates and sulphates on dairy cows. J. Food Agri. Environ. 3, 168-172.

KINAL, S., J. TWARDON, M. BEDNARSKI, J. PREŚ, R. BODARSKI, M. SLUPCZYNSKA, M. OCHOTA, G. J. DEJNEKA (2011): The influence of administration of biotin and zinc chelate ( $\mathrm{Zn}$ methionine) to cows in the first and second trimester of lactation on their health and productivity. Polish J. Vet. Sci. 14, 103-110.

DOI: $10.2478 / \mathrm{v} 10181-011-0015-\mathrm{x}$

KNOTT, L., J. F. TARLTON, H. CRAFT, A. J. F. WEBSTER (2007): Effects of housing, parturition and diet change on the biochemistry and biomechanics of the support structures of the hoof of dairy heifers. Vet. J. 174, 277-287.

DOI: 10.1016/j.tvj1.2006.09.007

LISCHER, C. J., P. OSSENT, M. RABER, H. GEYER (2002): Suspensory structures and supporting tissues of the third phalanx of cows and their relevance to the development of typical sole ulcers (Rusterholz ulcers). Vet. Rec. 151, 694-698.

LIVESEY, C. T., F. L. FLEMING C (1984): Nutritional influences on laminitis, sole ulcer and bruised sole in Friesian cows. Vet. Rec. 114, 510-512.

DOI: $10.1136 / v r .114 .21 .510$

MAJEE, D. N., E. C. SCHWAB, S. J. BERTICS, W. M. SEYMOUR, R. D. SHAVER (2003): Lactation performance by dairy cows fed supplemental biotin and a B-vitamin blend. J. Dairy Sci. 86, 2106-2112.

DOI: $10.3168 /$ jds.s0022-0302(03)73800-4

MANSKE, T., J. HULTGREN, C. BERGSTEN (2002): The effect of claw trimming on the hoof health of Swedish dairy cattle. Prev. Vet. Med. 54, 113-129.

DOI: $10.3168 /$ jds.s0022-0302(03)73800-4

MIDLA, L. T., K. H. HOBLET, W. P. WEISS, M. L. MOESCHBERGER (1998): Supplemental dietary biotin for prevention of lesions associated with aseptic subclinical laminitis (pododermatitis aseptica diffusa) in primiparous cows. Am. J. Vet. Res. 59, 733-738.

Vet. arhiv 89 (6), 799-820, 2019 
A. Singh et al.: Biotin-zinc supplementation in relation to hoof health and milk quality

MIGUEL-PACHECO, G. G., H. J. THOMAS, J. KALER, J. CRAIGON, J. N. HUXLEY (2016): Effects of lameness treatment for claw horn lesions on lying behaviour in dairy cows. Appl. Anim. Behav. Sci. 179, 11-16.

DOI: $10.1016 /$ j.applanim.2016.04.001

MOORE, C. L., P. M. WALKER, J. R. WINTER, M. A. JONES, J. M. WEBB (1989): Zinc methionine supplementation for dairy cows. Trans. Illinois Acad. Sci. 82, 99-108.

MORRIS, M. J., K. KANEKO, S. L. WALKER, D. N. JONES, J. E. ROUTLY, R. F. SMITH, H. DOBSON (2011): Influence of lameness on follicular growth, ovulation, reproductive hormone concentrations and estrus behavior in dairy cows. Theriogenology 76, 658-668.

DOI: 10.1016/j.theriogenology.2011.03.019

MULLING, C. K. W., H. H. BRAGUELLA, S. REESE, K. D. BUDRAS, W. STEINBERG (1999): How structures in bovine hoof epidermis are influenced by nutritional factors. Anat. Histol. Embryo. 28, 103-108.

DOI: 10.1046/j.1439-0264.1999.00180.x

MURRAY, R. D., D. Y. DOWNHAM, M. J. CLARKSON, W. B. FAULL, J. W. HUGHES, F. J. MANSON, J. B. MERRITT, W. B. RUSSELL, J. E. SUTHERST, W. R. WARD (1996): Epidemiology of lameness in dairy cattle: description and analysis of foot lesions. Vet. Rec. 138, 586-591.

DOI: $10.1136 /$ vr.138.24.586

NOCEK, J. E., A. B. JOHNSON, M. T. SOCHA (2000): Digital characteristics in commercial dairy herds fed metal-specific amino acid complexes. J. Dairy Sci. 83, 1553.

DOI: $10.3168 /$ jds.S0022-0302(00)75028-4

NOCEK, J. E., M. T. SOCHA, D. J. TOMLINSON (2006): The effect of trace mineral fortification level and source on performance of dairy cattle. J. Dairy Sci. 89, 2679-2693.

DOI: $10.3168 /$ jds.S0022-0302(06)72344-X

OFFER, J. E., D. N. LOGUE (1998): The effect of lameness in the dairy cow on the fatty acid profile of claw horn lipids. In: Proceedings of the $10^{\text {th }}$ International symposium on lameness in ruminants, (Lischer, C. J., P. Ossent, Eds.). Department of Veterinary Surgery, University of Zurich, Switzerland, pp. 220-221.

POTZSCH, C. J., V. J. HEDGES, R. W. BLOWEY, A. J. PACKINGTON, L. E. GREEN (2003): The impact of parity and duration of biotin supplementation of white line disease lameness in cattle. J. Dairy Sci. 86, 2577-2582.

DOI: $10.3168 /$ jds.s0022-0302(03)73852-1

RANDHAWA, S. S., K. DUA, C. S.RANDHAWA, S. K. MUNSHI (2008): Effect of biotin supplementation on hoof health and ceramide composition in dairy cattle. Vet. Res. Commun. 32, 599-608.

DOI: $10.1007 / \mathrm{s} 11259-008-9060-\mathrm{z}$

RANDHAWA, S. S., K. DUA, R. S. SINGH, P. S. DHALIWAL, A. K. SHARMA (2012): Effect of supplementation of zinc methionine on claw characteristics in crossbred dairy cattle. Indian J. Anim. Sci. 82, 304-308. 
A. Singh et al.: Biotin-zinc supplementation in relation to hoof health and milk quality

RUKOL, V. M. (2012): Milk quality parameters during treatment of cows with hoof diseases. Int. Vet. J. 2, 25-29.

SHEARER, J., S. VAN AMSTEL (2009): Toe lesions in dairy cattle. In: Proceedings of the 46th Florida dairy production conference, Gainesville.

SHEARER, J., S. VAN AMSTEL (2013): Manual of Foot Care in Cattle, $2^{\text {nd }}$ ed., Hoard's Dairyman, Fort Atkinson, WI.

SINGH, A., S. SINGH, D. K. GUPTA, B. K. BANSAL (2018): Relationship of lameness to body condition score, udder health and milk quality in crossbred dairy cattle. Vet. arhiv 88, 179-190.

DOI: $10.24099 /$ vet.arhiv.160907

SINGH, S. S., W. R.WARD, K. LAUTENBACH, R. D. MURRAY (1993): Behaviour of lame and normal dairy cows in cubicles and in a straw yard. Vet. Rec. 133, 204-208.

DOI: $10.1136 /$ vr.133.9.204

SMART, M., N. F. CYMBALUK (1997): Role of nutritional supplements bovine lameness - review of nutritional toxicities. In: Lameness in Cattle. (Greenough, P. R., A. D. Weaver, Eds.). $3^{\text {rd }}$ ed., W.B. Saunders Company, Philadelphia, pp. 145-161.

SOLANO, L., H. W. BARKEMA, E. A. PAJOR, S. MASON, S. J. LEBLANC, C. G. R. NASH, D. B. HALEY, D. PELLERIN, J. RUSHEN, A. M. DE PASSILLÉ, E. VASSEUR, K. ORSEL (2016): Associations between lying behavior and lameness in Canadian Holstein-Friesian cows housed in freestall barns. J. Dairy Sci. 99, 2086-2101.

DOI: $10.3168 /$ jds.2015-10336

TARLTON, J. F., D. E. HOLAH, K. M. EVANS, S. JONES, G. R. PEARSON, A. J. F. WEBSTER (2002): Biomechanical and histopathological changes in the support structures of bovine hooves around the time of first calving. Vet. J. 163, 196-204.

DOI: $10.1053 /$ tvj1.2001.0651

TOMLINSON, D. J., C. H. MULLING, T. M. FAKLER (2004): Invited Review: Formation of keratins in the bovine claw: roles of hormones, minerals, and vitamins in functional claw integrity. J. Dairy Sci. 87, 797-809.

DOI: $10.3168 /$ jds.S0022-0302(04)73223-3

TOUSSAINT-RAVEN, E., R. T. HAALSTRA, D. J. PETERSE (1985): Cattle Foot Care and Claw Trimming. Farming Press, Ipswich, UK.

VAN AMSTEL, S. R., J. K. SHEARER, F. L. PALIN (2004): Moisture content, thickness, and lesions of sole horn associated with thin soles in dairy cattle. J. Dairy Sci. 87, 757-763.

DOI: $10.3168 /$ jds.S0022-0302(04)73219-1

VAN AMSTEL, S. R., C. YOUNG, C. SCULLY, B. ROHRBACH (2016): Rate of horn growth, wear and sole thickness of dairy cattle in a free stall barn with concrete and rubber flooring. $\mathrm{J}$. Dairy Vet. Anim. Res. 4, 305-310.

DOI: $10.15406 / j d v a r .2016 .04 .00120$.

Vet. arhiv 89 (6), 799-820, 2019 
A. Singh et al.: Biotin-zinc supplementation in relation to hoof health and milk quality

VOIGT, J., H. HAGEMEISTER, S. KUHLA, U. SCHOENHUSEN, G. M. WEBER (2000): The effect of biotin supplementation on claw health in dairy cattle kept under field conditions. In: Proceedings of the $11^{\text {th }}$ International conference on bovine lameness, University of Parma, Parma, Italy, pp. 292-294.

WARNICK, L. D., D. JANSSEN, C. L. GUARD, Y. T. GRÖHN (2001): The effect of lameness on milk production in dairy cows. J. Dairy Sci. 84, 1988-1997.

DOI: $10.3168 /$ jds.S0022-0302(01)74642-5

WEISS, W. P., C. A. ZIMMERLY (2000): Effects of biotin on metabolism and milk yield of dairy cows. In: Proceedings of the $62^{\text {nd }}$ Cornell nutrition conference for feed manufacturers. Cornell University, Ithaca, NY, pp. 22-30.

WINCKLER, C., S. WILLEN (2001): The reliability and repeatability of a lameness scoring system for use as an indicator of welfare in dairy cattle. Acta. Agric. Scand. Sect. A. 30, 103-107.

DOI: $10.1080 / 090647001316923162$

ZIMMERLY, C. A., W. P. WEISS (2001): Effects of supplemental dietary biotin on performance of Holstein cows during early lactation. J. Dairy Sci. 84, 498-506.

DOI: $10.3168 /$ jds.S0022-0302(01)74500-6

Received: 31 December 2018

Accepted: 10 May 2019

\section{SINGH, A., S. S. RANDHAWA, R. S. SINGH: Učinak dodataka biotina i cinka na zdravlje papaka i kvalitetu mlijeka mliječnih krava. Vet. arhiv 89, 799-820, 2019. SAŽETAK}

Cilj ovoga istraživanja bio je procijeniti učinak dodataka biotina i cinkova sulfata (ZnSO4) na zdravlje papaka i kvalitetu mlijeka u mliječnih krava. Klinička hrome $(n=31)$ i zdrave krave $(n=28)$ odabrane su na temelju ocjene pokretljivosti (LS) te su slučajnim odabirom podijeljene u pokusnu i kontrolnu skupinu. Pokusnu skupinu činile su klinički hrome (CLT, $n=17)$ i zdrave $(H T, n=15)$ krave kojima je u hranu dodan 1 g $2 \%$-tnog biotina i $4 \mathrm{~g} \mathrm{ZnSO}_{4}$ dnevno tijekom 4 mjeseca, Kontrolnu skupinu činile su hrome krave (CLC, $\mathrm{n}=14$ i zdrave krave $(\mathrm{HC}, \mathrm{n}=13)$. Pokretljivost, tjelesna kondicija te kvaliteta i količina mlijeka procijenjeni su prije i nakon završetka istraživanja. Također, prije i poslije dodavanja dodataka hrani provedena je kirurška obrada papaka te je promatrana vrsta i težina oštećenja papaka. Debljina tabana (ST) stražnjih papaka nekih krava mjerena je ultrazvučno u pokusnoj i kontrolnoj skupini. Podaci su analizirani omjerom vjerodostojnosti hi-kvadrat testa i parnog $t$-testa. Na kraju istraživanja uočen je znakovit napredak LS-a $(\mathrm{P}<0,001)$; vjerodostojnosti hi-kvadrat testa i parnog $t$-testa. Neke su se od tih ocjena oštećenja pogoršale u krava u HC skupini krava. Debljina tabana povećala se u krava u pokusnoj skupini $(\mathrm{P}<0,05)$, dok je u krava u kontrolnoj skupini smanjena $(\mathrm{P}<0,05)$. Broj somatskih stanica u mlijeku (SCC) smanjen je $(\mathrm{P}<0,05)$, dok su prinos mlijeka $(\mathrm{P}<0,001)$ i sadržaj masti $(\mathrm{P}<0,05)$ povećani u krava u pokusnoj skupini. Također, utvrđeno je znakovito smanjenje prosječnog broja SCC-a $(\mathrm{P}<0,05)$ u zdravih krava u pokusnoj skupini. Zaključeno je da bi istodobno dodavanje biotina i cinkova sulfata u hranu moglo biti korisno u korekciji i prevenciji oštećenja papaka kao što bi moglo pridonijeti količini i kvaliteti mlijeka kod klinički hromih mliječnih krava.

Ključne riječi: mliječne krave; hromost; oštećenja papaka; biotin; cink; kvaliteta mlijeka 